\section{ANIS natarate \\ Journal of \\ Islamic Studies}

Institut Agama Islam Negeri (IAIN) Curup, Indonesia

ISSN 2580-3174, (p); 2580-3190 (e)

volume 6, number 2, 2021 | page: $263-276$

DOI: http://doi.org/10.29240/ajis.v6i2.3536

\title{
Analysis of Multicultural Understanding in the Villages of Sindang Jaya, Sindang Jati, and Suro Bali
}

\author{
Hendra Harmi \\ Insitut Agama Islam Negeri (IAIN) Curup, Indoneisa \\ hendra.harmi@iaincurup.ac.id
}

\begin{abstract}
This study aims to analyze the multicultural understanding in Sindang Jaya Village, Sindang Jati Village, and Suro Bali Village. Multicultural understanding is very important for instilling sympathy, respect, appreciation, and empathy towards adherents of different religions and cultures. The population taken in this study were all people who live in Sindang Jaya Village, Sindang Jati Village, and Suro Bali Village. The sampling technique used was purposive sampling with a total sample of 73 data, of which 23 people were from Sindang Jaya Village, 24 people were from Sindang Jati Village, and 26 people were from Suro Bali Village. The 73 respondents consisted of 33 Muslim respondents, 17 Buddhist respondents, 13 Hindus respondents, 9 Catholic respondents, and 1 Christian respondent. The data collection technique used was a non-test technique in the form of filling out a questionnaire. The instrument used in this study was a questionnaire sheet using a modified Likert scale with 4 answer choices. The results of the validity and reliability test indicated that the instrument used was valid and reliable. For the results of the analysis, the percentages for each respondent from the three villages are in the range of $76 \%-100 \%$ which enter the category of strongly agree based on the Likert scale interpretation table. This means that all respondents are categorized as strongly agree with the statements regarding the multicultural indicators proposed in the questionnaire. This shows that the people who live in Sindang Jaya Village, Sindang Jati Village, and Suro Bali Village have a high level of multicultural understanding.
\end{abstract}

Keywords: Multicultural, Sindang Jaya, Sindang Jati, Suro Bali

\section{Introduction}

Indonesia is one of the countries in Southeast Asia which has thousands of islands. Within the country, various tribes, races, religions, customs and cultures are scattered ${ }^{1}$. Indonesia has six religions that are

\footnotetext{
${ }^{1}$ Muhammad Sahal, Akhmad Arif Musadad, and Muhammad Akhyar, "Tolerance in Multicultural Education: A Theoretical Concept," International Journal of Multicultural and Multireligious Understanding 5, no. 4 (2018): 115, https://doi.org/10.18415/ijmmu.v5i4.212.
} 
recognized and approved by the state, namely Islam, Catholicism and Protestantism, Hinduism, Buddhism and Konhuchu. Therefore, multiculturalism is inevitable in Indonesia, and it is a national identity 2. Multiculturalism is a term used to describe cultural diversity or the recognition of cultural differences and the unification of different cultures. Multiculturalism is a condition in which there are recognized differences in race, ethnicity, language, sexual orientation, gender, age, class differences, education, religious/spiritual tendencies, and other cultural dimensions ${ }^{3}$. The term usually involves a positive evaluation of cultural diversity and an institutional commitment to its preservation ${ }^{4}$.

An understanding of multicultural values which are in accordance with the situation and conditions of the community is important so that people can live side by side with other communities ${ }^{5}$. Multicultural values are rooted in the concept of a pluralistic ideology which respects the cultural differences of people from different ethnic, religious, socioeconomic and geographical backgrounds ${ }^{6}$. In general, different ethnic and cultural groups that retain their original ethnic and cultural characteristics will be critical to the multicultural process of any nation state. However, if a group emphasizes its own characteristics too much, it will lead to conflict with other communities, which means diversification failure. It will even lead to extremism if contradictions and conflicts

2 Yeni Rahmawati, Pai Yi-Fong, and Hui-hua Chen, "The Necessity of Multicultural Education in Indonesia," International Journal of Education and Research 2, no. 10 (2014): 317-28.

${ }^{3}$ Mehmet Fatih Karacabey, Mustafa Ozdere, and Kivanc Bozkus, "The Attitudes of Teachers towards Multicultural Education," European Journal of Educational Research 8, no. 1 (2019): 383-93, https://doi.org/10.12973/eu-jer.8.1.383.

${ }^{4}$ Enzo Colombo, "Multiculturalisms: An Overview of Multicultural Debates in Western Societies," Current Sociology 63, no. 6 (2015): 800-824, https://doi.org/10.1177/0011392115586802.

5 Ida Zulaeha, "Innovation Models of Indonesian Learning in Multicultural Society," Procedia - Social and Behavioral Sciences 103 (2013): 506-14, https://doi.org/10.1016/j.sbspro.2013.10.367.

${ }^{6}$ Budi Setyono and Handoyo Puji Widodo, "The Representation of Multicultural Values in the Indonesian Ministry of Education and Culture-Endorsed EFL Textbook: A Critical Discourse Analysis," Intercultural Education 30, no. 4 (2019): 383-97, https://doi.org/10.1080/14675986.2019.1548102. 
cannot be resolved effectively ${ }^{7}$. Multiculturalists with high plurality of identities report higher levels of psychological burden, higher structural social capital, and higher levels of action and analytical skills than those with low identity plurality ${ }^{8}$.

The concept of multiculturalism is generally seen from ethnic backgrounds or racial differences, giving rise to negative views and concerns about the problem. It is therefore very important to provide a comprehensive education system where individuals in multicultural societies can live together in peace ${ }^{9}$. There is a relationship between multiculturalism and the educational process ${ }^{10}$. Multicultural education is an idea, educational reform and movement that aim to change the structure of educational institutions and the role of teachers to ensure that students from different racial, ethnic, linguistic and cultural groups have equal opportunities for academic achievement ${ }^{11}$. There are five dimensions of multicultural education, namely content integration, knowledge construction, equality pedagogy, prejudice reduction, and empowerment of school culture and social structures ${ }^{12}$. This dimension shows how educational textbooks and teachers integrate multicultural content and help students to understand the constructions of prejudice, authentic culture, social discrimination, and equality among ethnic

${ }^{7}$ Bo Wang and Jiani Wang, "Political Aspirations, Participations and Influence of Turkish Muslims in Germany," Journal of Middle Eastern and Islamic Studies (in Asia) 10, no. 2 (2016): 99-120, https://doi.org/10.1080/19370679.2016.12023284.

${ }^{8}$ Stacey R. Fitzsimmons, "A Framework for Understanding How They Contribute to Organizations," FAcademy of Management Review 38, no. 4 (2013): 525-49.

${ }^{9}$ Betul Tonbuloglu, Dolgun Aslan, and Hasan Aydin, "Teachers' Awareness of Multicultural Education and Diversity in School Settings," Eurasian Journal of Educational Research, no. 64 (2016): 1-28, https://doi.org/10.14689/ejer.64.1.

10 Merfat Ayesh Alsubaie, "Examples of Current Issues in the Multicultural Classroom," Journal of Education and Practice 6, no. 10 (2015): 86-89, http://search.ebscohost.com/login.aspx?direct=true \&db=eric\&AN=EJ1081654\&site=e host-live.

11 Hasan Aydin and Betul Tonbuloglu, “Graduate Students Perceptions' on Multicultural Education: A Qualitative Case Study," Eurasian Journal of Educational Research 14, no. 57 (2014): 29-50, https://doi.org/10.14689/ejer.2014.57.3.

12 Darnell Cole and Ji Zhou, "Do Diversity Experiences Help College Students Become More Civically Minded? Applying Banks' Multicultural Education Framework," Innovative Higher Education 39, no. 2 (2014): 109-21, https://doi.org/10.1007/s10755-013-9268-x. 
groups, and thereby develop positive racial attitudes ${ }^{13}$. Multicultural education also encourages students to maintain and celebrate their culture and ethnic identity ${ }^{14}$. In some countries, multicultural education is also implemented as evidence that they always involve struggles between people of color and whites. ${ }^{15}$

In Bengkulu Province, there are several regions that are famous for their diversity. First, Sindang Jaya Village. Sindang Jaya Village is a village located in Sindang Kelingi District, Rejang Lebong Regency. The area is in the composition of the community in terms of heterogeneous religions, namely Islam, which includes NU Islam, and LDII Islam, Catholicism, and Buddhism, which in their social life have coexisted for a long time without conflict, where they always establish good communication ${ }^{16}$. In the same sub-district, namely Sindang Kelingi District, there is also a village called Sindang Jati Village ${ }^{17}$. The village, which is located about 63 kilometers from the capital city of Bengkulu Province, has always cared for diversity, tolerance and religious harmony since 1962. There are four religions followed by the local community, namely: Islam, Catholicism, Christianity, and Buddhism. They are known to always cooperate in every event of religious and state celebrations and develop the community's economy without being limited by religious barriers.

${ }^{13}$ Ayami Nakaya, "Overcoming Ethnic Conflict through Multicultural Education: The Case of West Kalimantan, Indonesia," International Journal of Multicultural Education 20, no. 1 (2018): 118-37, https://doi.org/10.18251/ijme.v20i1.1549.

14 Amirullah Abduh et al., "Voices of English Department Students on Multicultural Values in an Indonesian Islamic Higher Education," International Journal of Language Education 4, no. 3 (2020): 459-68, https://doi.org/10.26858/ijole.v4i3.17829.

15 Christine Sleeter, "Multicultural Education Past, Present, and Future: Struggles for Dialog and Power-Sharing Intercultural Education Multicultural Education Comes into Being Twenty-Two Years and Two Emblematic Experiences Ago Elites React Neoliberal Multicultural Education?," International Journal of Multicultural Education 20, no. 1 (2018): 5-20.

${ }^{16}$ Idi Warsah, Amelia Avisa, and Anrial, "Pola Komunikasi Antar Umat Beragama Masyarakat Desa Sindang Jaya, Rejang Lebong, Bengkulu," Ar-Risalah: Media Keislaman, Pendidikan XVIII, no. 2 (2020): 283-307.

17 Oriza Sativa, Yuwana Yuwana, and Bonodikun Bonodikun, "Physical Characteristics of Fruit, Beans, and Powder of Coffee Harvested From Sindang Jati Village, Rejang Lebong District," Jurnal Agroindustri 4, no. 2 (2014): 65-77, https://doi.org/10.31186/j.agroind.4.2.65-77. 
In addition to the two villages in Rejang Lebong Regency, there is also a village located in a neighboring district whose people live in diversity. The village is named Suro Bali Village. Suro Bali Village is precisely located in Ujan Mas District, Kepahiang Regency 18. At the beginning of its formation, the village was inhabited by 4 heads of families (KK) who were all Balinese and Hindu. The name Suro Bali is taken from the previous parent village, namely Suro Mucar Village. While the name Bali was taken considering the origin of the population in the village which was dominated by ethnic Balinese. Until now, Balinese ethnic people who embrace Hinduism are still the majority population there ${ }^{19}$. In Suro Bali Village, although the community members are in heterogeneity in culture and belief or called multi-religion, there has never been a conflict caused by these differences ${ }^{20}$.

Based on his description above, it is known that multicultural understanding is very important for Indonesian people, especially people who live in areas known for their diversity such as Sindang Jaya Village, Sindang Jati Village, and Suro Bali Village. Therefore, the researcher decided to conduct an analysis of the level of multicultural understanding in 3 villages in Bengkulu Province, namely, Sindang Jaya Village, Sindang Jati Village, and Suro Bali Village through 3 assessment aspects, namely from cultural aspects, political aspects, economic aspects, and educational aspects.

The population taken in this study were all people who live in Sindang Jaya Village, Sindang Jati Village, and Suro Bali Village. The sampling technique used was purposive sampling with a total sample of 73 data, of which 23 people were from Sindang Jaya Village, 24 people

${ }_{18}$ Mesi Anggraini, Choirul Muslim, and Santi Nurul Kamilah, "Morfometri Kepala Dan Wajah Pada Masyarakat Suku Bali Di Desa Suro Bali Kecamatan Ujan Mas Kabupaten Kepahiang Provinsi Bengkulu," Konservasi Hayati 16, no. 2 (2020): 71-76, https://doi.org/10.33369/hayati.v16i2.12448.

19 Idi Warsah, "Relevansi Relasi Sosial Terhadap Motivasi Beragama Dalam Mempertahankan Identitas Keislaman Di Tengah Masyarakat Multi Agama (Studi Fenomenologi Di Desa Suro Bali Kepahiang Bengkulu)" Kontekstualita: Jurnal Penelitian Sosial Dan Keagamaan 34, no. 2 (2017): 149-77.

20 Idi Warsiah, "Pendidikan Keluarga Muslim Di Tengah Masyarakat MultiAgama: Antara Sikap Keagamaandan Toleransi (Studi Di Desa Suro Bali KepahiangBengkulu)" Edukasia: Jurnal Penelitian Pendidikan Islam 13, no. 1 (2018): 1-24. 
were from Sindang Jati Village, and 26 people were from Suro Bali Village. The 73 respondents consisted of 33 Muslim respondents, 17 Buddhist respondents, 13 Hindus respondents, 9 Catholic respondents, and 1 Christian respondent. This research was conducted in September 2021. The data collection technique used a non-test technique in the form of filling out a questionnaire consisting of 5 statements from the religious aspect, 6 statements from the cultural aspect, 4 statements from the political aspect, 4 statements from the economic aspect, and 6 statements from the education aspect. The data collection technique used a non-test technique in the form of filling out a questionnaire. The instrument used in this study was a questionnaire sheet using a modified Likert scale with 4 answer options, namely Strongly Agree, Agree, Disagree, and Strongly Disagree. The questionnaire was tested for validity and reliability with the following conditions:

Valid : if rcount is greater than rtable value (rcount $>$ rtable)

Invalid : if rcount is less than rtable value (rcount $<$ rtable)

Reliable if Cronbach's alpha value $>0.60$

Not reliable if Cronbach's alpha value $<0.60^{21}$.

Analysis of the results of the questionnaire was carried out quantitatively using the following formula.

$$
p=\frac{n}{N} \times 100 \%
$$

where $P$ is the percentage of the results of the questionnaire analysis, $\mathrm{n}$ is the total score of the assessment, and $\mathrm{N}$ is the maximum possible score. For the Likert scale, the score interpretation model can be seen in table 1 .

Table 1. Likert Scale Interpretation

\begin{tabular}{cc}
\hline Percentage (\%) & Category \\
\hline $0 \%-25 \%$ & Strongly Disagree \\
$26 \%-50 \%$ & Disagree \\
$51 \%-75 \%$ & Agree \\
$76 \%-100 \%$ & Strongly agree \\
\hline
\end{tabular}

${ }^{21}$ Budiwibowo Kukuh Arief \& Nurhalim Khomsun, "Pengaruh Motivasi Belajar Terhadap Prestasi Belajar Warga Belajar Kejar Paket C," Journal of Nonformal Education 2, no. 2 (2016): 168-174. 
After this research was conducted, the data was obtained regarding the level of multicultural understanding in Sindang Jaya Village, Sindang Jati Village, and Suro Village Bali.

\section{Results and Discussion}

Prior to further analysis, the instrument used in this study was tested for the validity and reliability of the instrument. These two tests were conducted to determine whether the questionnaire that had been made met the accuracy requirements or not. In practice, these two tests were carried out with the help of SPSS software. The validity test used in this study was the content validity test. Content validity test was used to prove the accuracy of the item with the content. In the content validity test, the Pearson coefficient value was used. The decision was taken from the comparison between the calculated person coefficient value ( $r_{\text {count }}$ ) and the Pearson coefficient table ( $r_{\text {table }}$ ). If the value of $r_{\text {count }}>r_{\text {table, }}$ it can be stated that the question items on the questionnaire are valid. Reliability test is used to test the level of consistency of the questionnaire. The reliability test used in this study was the internal consistency technique with Cronbach's alpha technique. A questionnaire is said to be reliable if Cronbach's alpha value $>0.6023$.

In this study, there were 73 respondents so that the Pearson table coefficient value (rtable) of $\mathrm{df}=71$ is 0.2303 at a significance level of 5\%. The results of the validity test on each statement item can be seen in the following table

Table 2. Validity Test Results on Each Statement Item

\begin{tabular}{cccc}
\hline $\begin{array}{c}\text { Number } \\
\text { of Item }\end{array}$ & $\mathrm{r}_{\text {count }}$ & $\mathrm{rtable}$ & Category \\
\hline 1 & 0.321364 & 0.2303 & Valid \\
2 & 0.446509 & 0.2303 & Valid
\end{tabular}

${ }^{22}$ Sri Hayati, Agus Setyo Budi, and Erfan Handoko, "Pengembangan Media Pembelajaran Flipbook Fisika Untuk Meningkatkan Hasil Belajar Peserta Didik," Prosiding Seminar Nasional Fisika (e-Jurnal) SNF2015 4 (2015): 49-54.

${ }^{23}$ Dessy Triana and Wahyu Oktri Oktavianto, "Relevansi Kualifikasi Kontraktor Bidang Teknik Sipil Terhadap Kualitas Pekerjaan Proyek Konstruksi Di Provinsi Banten," Jurnal Fondasi 1, no. 1 (2013): 182-90. 


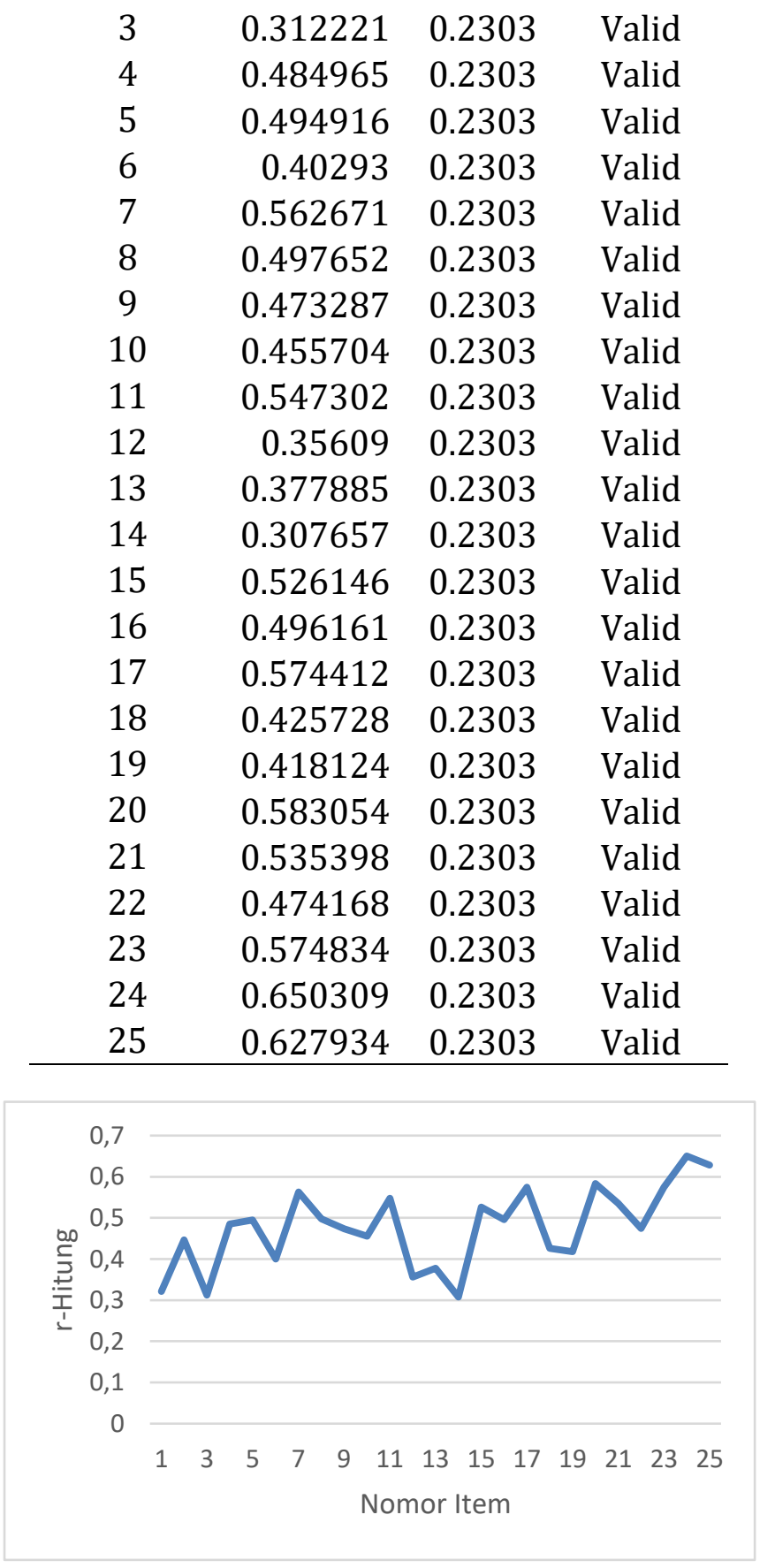

Figure 1. $r_{\text {count }}$ Value of Each Item

From the table above, information is obtained that all statement items written in the questionnaire are valid because all items have $r$ count which is greater than rable. 
For the results of the reliability test can be seen in the following table

Table 3. Reliability Statistics

\begin{tabular}{r|r} 
Cronbach's Alpha & N of Items \\
\hline 0855 & 25 \\
\hline
\end{tabular}

From the table above, it is known that the Cronbach Alpha value obtained is 0.855 with a total of 25 items being tested. In accordance with the rules used, if the Cronbach's Alpha value is greater than 0.60 , then the instrument is said to be reliable.

To determine the level of multicultural understanding in Sindang Jaya Village, Sindang Jati Village, and Suro Village Bali, the percentage of the results of filling out the questionnaires that had been distributed was calculated, the results can be seen in the following table.

Table 4. Percentage of Level of Approval of the Sindang Jaya, Sindang Jati, and Suro Bali Villages towards Statements Regarding Multicultural Indicators Mentioned in the Questionnaire

\begin{tabular}{|c|c|c|c|c|}
\hline Respondent & $\begin{array}{c}\text { Total } \\
\text { Score } \\
\text { (n) }\end{array}$ & $\begin{array}{l}\text { Maximum } \\
\text { Score (N) }\end{array}$ & $\begin{array}{c}\text { Percentage } \\
P=x 100 \\
\frac{n}{N} \%\end{array}$ & Category \\
\hline $\begin{array}{l}23 \text { people from } \\
\text { Sindang Jaya } \\
\text { Village }\end{array}$ & 1983 & 2300 & $86.21 \%$ & $\begin{array}{l}\text { Strongly } \\
\text { agree }\end{array}$ \\
\hline $\begin{array}{l}24 \text { people in } \\
\text { Sindang Jati } \\
\text { Village }\end{array}$ & 2113 & 2400 & $88.04 \%$ & $\begin{array}{l}\text { Strongly } \\
\text { agree }\end{array}$ \\
\hline $\begin{array}{l}26 \text { people from } \\
\text { Suro Bali } \\
\text { Village }\end{array}$ & 2253 & 2600 & $86.65 \%$ & $\begin{array}{l}\text { Strongly } \\
\text { agree }\end{array}$ \\
\hline $\begin{array}{l}\text { The table } \\
\text { Sindang Jaya Vill } \\
\text { agree with the sta } \\
\text { in the questionn } \\
\text { multiculturalism } \\
\text { fact which are th }\end{array}$ & $\begin{array}{l}\text { bove pr } \\
\text { e, Sinda } \\
\text { ments } r \\
\text { re. This } \\
\text { ith the }\end{array}$ & $\begin{array}{l}\text { des informat } \\
\text { Jati Village, a } \\
\text { rding the mu } \\
\text { ows that the } \\
\text { ciple that di }\end{array}$ & $\begin{array}{l}\text { that both th } \\
\text { Suro Bali Vill } \\
\text { ultural indicat } \\
\text { have an under } \\
\text { rences are an }\end{array}$ & $\begin{array}{l}\text { people of } \\
\text { ge strongly } \\
\text { ors included } \\
\text { standing of } \\
\text { inavoidable } \\
\text { so that they }\end{array}$ \\
\hline
\end{tabular}


do not consider their cultural elements to be more valuable than other people's cultural elements, as well as religious elements, political aspirations, economic differences and educational differences. On the religious aspect, respondents stated that they lived in harmony and respected each other eventhough the people where they lived had different religions. They agreed that as a nation that had religious diversity, building the Indonesian nation had to begin with the belief that with unity we had greater strength. In addition, it must also be instilled that everyone is obliged to respect others regardless of religious differences. They claimed to get along well even though they had different beliefs and were not easily provoked by issues related to SARA that could divide religious communities in society. On the cultural aspect, they stated that culture in Indonesia was the wealth of the nation because each culture had its own advantages and characteristics, therefore regional culture had to be respected and preserved by each member of the local community. One way is that the younger generation must study, care for, and develop cultural heritage so that cultural identity is maintained and sustainable and everyone must be able to maintain cultural values that exist in society. The cultural values possessed by individuals influence and color in the association in society so that differences in cultural backgrounds in society should not be the basis for divisions in society. On the political aspect, they stated that everyone had the right to give their aspirations to politics regardless of differences in culture, religion, education, and economy so that regional or central officials were obliged to accommodate the aspirations of the community regardless of cultural, religious, educational and economic differences. Everyone is obliged to respect and respect the aspirations of others in the political field and differences in political aspirations must not divide the harmony that exists in society. On the economic aspect, they stated that they worked together in social activities. Regardless of economic differences, every community must be able to explore the potential that exists in their area to help improve the standard of living of the economy, the spirit of togetherness and mutual cooperation can help grow the economy in the community, and help and pay attention to underprivileged communities is the duty of every member of the surrounding community. In terms of education, according to them, working together in social activities is a 
shared obligation regardless of differences in educational background. Education can improve the quality of people's lives, Mutual help must be instilled in everyone looking at educational differences. Every citizen has the right to get a proper education regardless of ethnicity, race and religion, the diversity that exists in a community group does not become a barrier for someone to get an education, and good educational facilities and infrastructure can improve the quality of education. By agreeing to such statements, it means that they already have a good understanding of multiculturalism. The attitude of mutual help must be instilled in everyone looking at differences in education, every citizen has the right to get a proper education regardless of ethnicity, race and religion. The diversity that exists in a community group does not become a barrier for someone to get education, as well as educational facilities and infrastructure that are adequate. Good educational facilities and infrastructure can improve the quality of education. By agreeing to such statements, it means that they already have a good understanding of multiculturalism.

\section{Conclusion}

From the results of the study, it was concluded that the instrument used was valid and reliable. For the results of the analysis, the percentages of the three villages are in the range of $76 \%-100 \%$ which fall into the category of strongly agree based on the Likert scale interpretation table. This means that all respondents are categorized as strongly agree with the statements regarding multicultural indicators both in the aspects of religion, culture, politics, economy, and education proposed in the questionnaire. This shows that the people who live in Sindang Jaya Village, Sindang Jati Village, and Suro Bali Village already have a multicultural understanding.

\section{Bibliography}

Abduh, Amirullah, Muhammad Basri, Shafa, Andi Anto Patak, and Rosmaladewi. "Voices of English Department Students on Multicultural Values in an Indonesian Islamic Higher Education." International Journal of Language Education 4, no. 3 (2020): 45968. https://doi.org/10.26858/ijole.v4i3.17829. 
Alsubaie, Merfat Ayesh. "Examples of Current Issues in the Multicultural Classroom." Journal of Education and Practice 6, no. 10 (2015): 8689.

http://search.ebscohost.com/login.aspx?direct=true\&db=eric\&A $\mathrm{N}=\mathrm{EJ} 1081654 \&$ site $=$ ehost-live.

Anggraini, Mesi, Choirul Muslim, and Santi Nurul Kamilah. "Morfometri Kepala Dan Wajah Pada Masyarakat Suku Bali Di Desa Suro Bali Kecamatan Ujan Mas Kabupaten Kepahiang Provinsi Bengkulu." Konservasi Hayati 16, no. 2 (2020): 71-76. https://doi.org/10.33369/hayati.v16i2.12448.

Aydin, Hasan, and Betul Tonbuloglu. "Graduate Students Perceptions' on Multicultural Education: A Qualitative Case Study." Eurasian Journal of Educational Research 14, no. 57 (2014): 29-50. https://doi.org/10.14689/ejer.2014.57.3.

Budiwibowo Kukuh Arief \& Nurhalim Khomsun, "Pengaruh Motivasi Belajar Terhadap Prestasi Belajar Warga Belajar Kejar Paket C," Journal of Nonformal Education 2, no. 2 (2016): 168-174

Cole, Darnell, and Ji Zhou. "Do Diversity Experiences Help College Students Become More Civically Minded? Applying Banks' Multicultural Education Framework." Innovative Higher Education 39, no. 2 (2014): 109-21. https://doi.org/10.1007/s10755-0139268-x.

Colombo, Enzo. "Multiculturalisms: An Overview of Multicultural Debates in Western Societies." Current Sociology 63, no. 6 (2015): 800-824. https://doi.org/10.1177/0011392115586802.

Fitzsimmons, Stacey R. "A Framework for Understanding How They Contribute to Organizations." FAcademy of Management Review 38, no. 4 (2013): 525-49.

Hayati, Sri, Agus Setyo Budi, and Erfan Handoko. "Pengembangan Media Pembelajaran Flipbook Fisika Untuk Meningkatkan Hasil Belajar Peserta Didik." Prosiding Seminar Nasional Fisika (e-Jurnal) SNF2015 4 (2015): 49-54.

Karacabey, Mehmet Fatih, Mustafa Ozdere, and Kivanc Bozkus. "The 
Attitudes of Teachers towards Multicultural Education." European Journal of Educational Research 8, no. 1 (2019): 383-93. https://doi.org/10.12973/eu-jer.8.1.383.

Nakaya, Ayami. "Overcoming Ethnic Conflict through Multicultural Education: The Case of West Kalimantan, Indonesia." International Journal of Multicultural Education 20, no. 1 (2018): 118-37. https://doi.org/10.18251/ijme.v20i1.1549.

Rahmawati, Yeni, Pai Yi-Fong, and Hui-hua Chen. "The Necessity of Multicultural Education in Indonesia." International Journal of Education and Research 2, no. 10 (2014): 317-28.

Sahal, Muhammad, Akhmad Arif Musadad, and Muhammad Akhyar. "Tolerance in Multicultural Education: A Theoretical Concept." International Journal of Multicultural and Multireligious $\begin{array}{llllll}\text { Understanding } \quad 5, \quad \text { no. } 4 & 4 & \text { (2018): } & 115 .\end{array}$ https://doi.org/10.18415/ijmmu.v5i4.212.

Sativa, Oriza, Yuwana Yuwana, and Bonodikun Bonodikun. "Physical Characteristics of Fruit, Beans, and Powder of Coffee Harvested From Sindang Jati Village, Rejang Lebong District." Jurnal Agroindustri 4, no. 2 (2014): 65-77. https://doi.org/10.31186/j.agroind.4.2.65-77.

Setyono, Budi, and Handoyo Puji Widodo. "The Representation of Multicultural Values in the Indonesian Ministry of Education and Culture-Endorsed EFL Textbook: A Critical Discourse Analysis." Intercultural Education 30, no. 4 (2019): 383-97. https://doi.org/10.1080/14675986.2019.1548102.

Sleeter, Christine. "Multicultural Education Past, Present, and Future: Struggles for Dialog and Power-Sharing Intercultural Education Multicultural Education Comes into Being Twenty-Two Years and Two Emblematic Experiences Ago Elites React Neoliberal Multicultural Education?" International Journal of Multicultural Education 20, no. 1 (2018): 5-20.

Tonbuloglu, Betul, Dolgun Aslan, and Hasan Aydin. "Teachers' Awareness of Multicultural Education and Diversity in School Settings." 
Eurasian Journal of Educational Research, no. 64 (2016): 1-28. https://doi.org/10.14689/ejer.64.1.

Triana, Dessy, and Wahyu Oktri Oktavianto. "Relevansi Kualifikasi Kontraktor Bidang Teknik Sipil Terhadap Kualitas Pekerjaan Proyek Konstruksi Di Provinsi Banten." Jurnal Fondasi 1, no. 1 (2013): 182-90.

Wang, Bo, and Jiani Wang. "Political Aspirations, Participations and Influence of Turkish Muslims in Germany." Journal of Middle Eastern and Islamic Studies (in Asia) 10, no. 2 (2016): 99-120. https://doi.org/10.1080/19370679.2016.12023284.

Warsah, Idi. “Relevansi Relasi Sosial Terhadap Motivasi Beragama Dalam Mempertahankan Identitas Keislaman Di Tengah Masyarakat Multi Agama (Studi Fenomenologi Di Desa Suro Bali Kepahiang Bengkulu)." Kontekstualita: Jurnal Penelitian Sosial Dan Keagamaan 34, no. 2 (2017): 149-77.

Warsah, Idi, Amelia Avisa, and Anrial. "Pola Komunikasi Antar Umat Beragama Masyarakat Desa Sindang Jaya, Rejang Lebong, Bengkulu." Ar-Risalah: Media Keislaman, Pendidikan XVIII, no. 2 (2020): 283-307.

Warsiah, Idi. "Pendidikan Keluarga Muslim Di Tengah Masyarakat MultiAgama: Antara Sikap Keagamaandan Toleransi ( Studi Di Desa Suro Bali Kepahiang-Bengkulu)" Edukasia: Jurnal Penelitian Pendidikan Islam 13, no. 1 (2018): 1-24.

Zulaeha, Ida. "Innovation Models of Indonesian Learning in Multicultural Society." Procedia - Social and Behavioral Sciences 103 (2013): 506-14. https://doi.org/10.1016/j.sbspro.2013.10.367. 